\title{
Botanical Poetry as a Means of Promoting Humankind's Well-being and Revaluing a Desert Ecosystem
}

\author{
Diana Woodcock
}

School of the Arts, Virginia Commonwealth University in Qatar, Qatar

Copyright $(\mathcal{C} 2015$ by authors, all rights reserved. Authors agree that this article remains permanently open access under the terms of the Creative Commons Attribution License 4.0 International License

\begin{abstract}
This paper features an overview of my research project, as well as some of the poems from my work-in-progress, The Desert's Botanical Bounty: Poems from the Heart of the Arabian Desert, a collection of poetry promoting a greater appreciation of and commitment to protecting not only the unique environment of the Arabian Peninsula, but other equally endangered ecosystems around the world. My goal is to emphasize that when we abuse the land, we contribute to an increase in poverty and a deterioration of health of our fellow human beings.
\end{abstract}

Keywords Poverty, Ecology, Theology, Environment

\section{Introduction}

Qatar's biosphere, like that of many other countries today, is in crisis due to the country's radical economic expansion as it supplies oil and gas to the world and prepares to host the 2022 World Cup. Because of this, and in anticipation of the opening of Qatar's UNESCO-sponsored Quranic Botanic Garden (the purpose of which is to maintain for scientific and educational purposes a living collection of Qatar's 270-plus indigenous plants and to showcase the ones mentioned more than once in the Quran), I have been preparing a poetry manuscript that features the ecology and flora of this tiny country jutting out into the Arabian Gulf. Having lived for ten years now in this oil-rich land at the edge of the Arabian Desert, I have become increasingly interested in local and global conservation issues, and in how these issues impact the most impoverished members of society. The Arabic concept of hema, loosely translated as the nomadic sense of respect and protection of the environment, is neglected as the country is being overdeveloped. Qatar has gone from being one of the poorest countries to being one of the richest in the world due to the discovery of oil. Previously, it was dominated by nomadic and semi-nomadic people dependent on fishing, pearling, camel breeding and dhow construction. Now numbered among the world's wealthiest, the Qatari people rely on an expatriate workforce made up of the poorest members of India, Pakistan, the Philippines and other impoverished nations to toil in inhospitable conditions to build their roads, hotels, houses, shopping centers, etc.

Since 2004, I have gone out into Qatar's desert on a regular basis to observe and record Qatar's flora. Currently a $\mathrm{PhD}$ candidate (Creative Writing) at Lancaster University, I have chosen two major questions to drive my research: Why have such devout Muslims strayed so far from the environmental ethic of the Quran? And what can poetry and botanical gardens accomplish that a scientific treatise or textbook cannot? The interdisciplinary aspects of my research include botany, cultural studies, and Islamic studies. These, coupled with field visits, observation, and interviews with the nine Qatar Foundation and UNESCO employees assigned to the Quranic Botanic Garden and members of the multidisciplinary scientific team developing and implementing the plans for the garden-specialists in Islam, Islamic art, botany, and the environment-inform the poems I will share with you today -- poems from my work-in-progress, The Desert's Botanical Bounty: Poems from the Heart of the Arabian Desert, a collection of poetry promoting a greater appreciation of and commitment to protecting not only the unique environment of the Arabian Peninsula, but other equally endangered ecosystems around the world. My goal is to emphasize, through the medium of poetry, that when we abuse the land, we contribute to an increase in poverty and a deterioration of health of our fellow human beings.

Qatar's degraded environment is causing physical and psychological problems for some of the world's wealthiest people, as well as for the county's expatriate workers $-70.9 \%$ of the total population - mostly coming from impoverished countries [1]. Botanical gardens are recognized now for their increasing social importance in connecting people to their communities and in educating them to issues of sustainable development and biodiversity conservation. The proposed UNESCO-sponsored Quranic Botanic Garden may play a key role in transforming Doha and helping residents revalue the ecosystem they inhabit.

When I first submitted my proposal for this conference, I wondered how I was going to make a case for botanical 
gardens having a place in this discussion. Fortunately, I have just come from a 3-day International Forum of the Qur'anic Botanic Garden, Islamic Perspectives on Ecosystem Management, in which participants shared many examples of how botanical gardens are making contributions to poverty reduction and ecological justice. One such example came from Her Highness Princess Basma bint Ali, founder of the Royal Botanical Gardens of Jordan. She shared highlights from one of their key projects, a community-based rangeland rehabilitation project, the purpose of which is to tackle the issues of habitat loss and food security in Jordan. Since the project began in 2007, it has doubled the salaries and improved the health of the livestock herding families of the region [2]. It was emphasized by several keynote speakers that poverty is indeed an environmental issue, and that as the role of botanical gardens has evolved in the past 40 years so that now conservation is a key component of it, surely botanical gardens will continue to aid in poverty reduction and ecological justice.

The poems in my proposed collection, just like the proposed Quranic Botanic Garden, will build on the strong links between cultural heritage and biological diversity conservation while providing an educational, scientific and cultural network promoting research and botanical studies on the Arabian Peninsula. As author Kamal El Batanouny has pointed out, Qatar's young people know nothing about Qatar's native plants [3]. My book will help educate through poetry, which continues to be well respected in the Arab culture.

The goal of my book project is in sync with the goal of the botanic garden project: to make a major contribution to environmental conservation, scientific research, and education revolving around Qatar's indigenous plants and the ones mentioned more than once in the Quran. My book will contribute to a greater appreciation of and commitment to protecting the unique environment of the Arabian Peninsula, as well as promoting Gulf Arabs' well-being.

Hopefully, The Desert's Botanical Bounty: Poems from the Heart of the Arabian Desert will be published in time to be displayed at the opening (slated for 2016) of Qatar's globally unique botanic garden. It is my intention that The Desert's Botanical Bounty: Poems from the Heart of the Arabian Desert will live up to one particular aspect of my university's vision statement, which is that research and discovery should advance knowledge, inspire creativity, and improve health. Through these poems, I am attempting to connect people to their land and inspire them to protect that environment from further pollution and misuse. My project, through creative expression, will advance knowledge of how Qatar's natural world and human health are connected.

Following are a few of the poems from this work in progress. The first one is dedicated to the man who so graciously has escorted my colleagues and me out into the desert on numerous occasions to search for endemic plants of the region.

\section{For Ali Sharif, Wildflower Expert}

A yellow dwarf radiates photons

onto Earth, and impeccably

tailored flowers unfold their petals

like the oppressed unfurling flags

in protest against hunger

and poverty, but mostly against

desperation.

Magnanimous wildflowers,

theirs the most unsordid act

of the day. Don't interrupt.

Let them have their say, after which you may well decide

silence is the only

appropriate reply.

\section{Quranic Botanic Garden}

Inauguration Day, September 2008

A sidra sapling is planted at the proposed site. Around it will grow three hundred species of local flora, the Quran's ninety, the Hadith's fifty—mustard, saffron, pumpkin, henna, pomegranate to name a few. A garden

designed like a traditional quadripartitefour quarters, water canals, a central fountainspread over twenty-four hectares knowledge from the Holy Book's one hundred and fifty verses depicting divine flora.

What a sight to see-such diverse heads in concert: botanists and phytochemists, engineers and architects, Muslim scholars all agreeing on grapes, figs, date palms, pomegranates just at the eleventh hour of habitat loss, oil spills, inadequate livestock management. Plan well, dear experts: wadis, baadiya, rodats, oases, sunken flower-beds, gulistans, bustans, plants from the coast, the hills and gravel plains, sandy terrain, aquatic habitats (Inland Sea and wadis). Don't forget the salt-tolerant halophytes. Grace this modern metropolis with a space for reverie, for desert mind to hear a unified botanical voice rising out of primordial sand.

Don't dawdle. Be quick and firm before one more specia is lost.

Lead us into plant presence - not one of us as clever as the cactus with its spikes and prickles, the acacia with its knack for attracting fine

waterborne sediments - wisely folding its petals by midday. Place before us a date palm just as its fruit is ripening, beckoning to the passage migrants. Don't delay. 
Build for us today a Quranic Botanic Garden.

Let the sidra sapling grow up strong and straighta sacred Lote tree - to lead us into holy presence. But simultaneously, let us protect the wildthe camel thorn for starters, for those sure-footed ships of the desert to graze.

My goal with these next few poems is to begin articulating for the reader the Islamic environmental ethic and view of the cosmic order. They provide a backdrop for readers unfamiliar with desert ecology. With "Islam and Ecology," I attempt to underscore the Islamic belief in the sacredness of all of nature and the Muslim's responsibility to care for the earth. The essence of Islamic teaching is that the entire universe is Allah's creation. This is what I am trying to capture in the short lines of this poem. The word 'Islam' has the dual meaning of submission and peace, and I am suggesting that by turning "our faces sunflower-like/ to the blaze every single hour/ of our fleeting earthly sojourn/ in perfect unity and praise," we will be submitting and thus living in peace.

\section{Islam and Ecology}

The seven heavens and the earth and all therein declare His glory:

there is not a thing but celebrates His praise ... -- Qur'an 17:44

The problem begins

with separation of science

from the sacred, religion

from the secular; with denial

nature comes from a higher,

holier realm. Once the gist

of vicegerency is misconstrued,

nature's screwed.

Only one way will save it-

relive its sacredness,

bear witness to these truths:

nature depicts like an icon

the Creator-reflects Paradise,

memories kept in the soul's depths;

divine grace, barakak, flows

through arteries of the natural

and cosmic world order.

At every chance we must-

above all at dawn and dusk-

make the fields and forests,

desert flats and mountain peaks,

sky and sea our libraries;

inquire of the crows

what all they know;

follow the shooting star

to places near and far;

pace the shoreline sandpiper-

like, seeking sustenance; turn our faces sunflower-like

to the blaze every single hour

of our fleeting earthly sojourn

in perfect unity and praise.

In "Yet in August," I introduce some of the plants mentioned in the Quran and continue the theme of praise and the Islamic conviction that the Creator can be known through observation of His creation. With "dormant seeds waiting for winter rains," I sustain the emphasis on the theme of submission. Islam, being a very practical world view, has adopted principles and directives that give pragmatic shape to its concepts and values. Its environmental ethic is no exception. This poem is an attempt to suggest that we must care for the "barren waste" as well as the cultivated.

\section{Yet in August}

Torn between the trellised and untrellised, I praise plants from the Holy Qur'an,

cultivated fruit trees - date palm, pomegranate, olive,

fig, ginger, grape,

Christ's thorn (sidra tree);

plants from the Hadith and Sunna -

Camel's hay, citron, orfot and True senna.

Praise plants that bring me face to face with creation, resurrection.

Yes, praise beet and kust.

Praise annuals - the cultivated:

onion, leek, and garlic;

mustard and sesame;

safflower and wheat;

rice and barley; lentil and

Black cumin.

Praise creepers and climbers:

melons; pumpkins; gourds.

Praise wild perennial herbs:

'heart of the desert' ones like Bitter gourd;

aquatic ones - wild ginger, cust root,

sweet flag, Narrow-leaved cattail, saffron.

Praise cultivated perennial herbs:

aloe, sweet basil. Praise desert shrubs:

Toothbrush tree and Salt tree;

cultivated shrubs Henna and Katam.

Praise wild desert trees: acacia,

Umbrella thorn, tamarisk.

Praise tropical/subtropical trees:

camphor, kamala, banana.

August gardens overflowing,

shamal winds blowing

over the arid desert landscape.

Mirages like mirrors. 
Heat rising like incense

from the desert's heart.

Dormant seeds waiting for winter rains.

Beyond the tended garden,

not a hint of green.

Austere grace of a barren waste.

One Crested lark cries out against stark reality.

But oh the sound one dormant seed can make splitting open hard-packed ground, exposing parched earth's intimacies.

Yet in August, redemptive winter rains seeming most improbable.

This next poem zeroes in on one species. By comparing human beings to the acacia (Broken are we, out of sync with the universe/ while the acacia has not strayed one millimeter/ from the sacred way), I am suggesting we have much to learn from nature and its faithfulness to its purpose. As I allude to how we are destroying His handiwork, I am emphasizing the Islamic directive to protect all that Allah has created.

\section{Acacia}

Eating ice cream and candy, I give thanks for the acacia for its Gum arabic.

In the desert, I come into the shade of one and praise its slanted, flat top.

Admire its wisdom: small leaves for conserving water; thorns and prickles keeping grazers at bay;

the heartwood's deposits of metabolic wastes serving as preservatives making it unpalatable

to abrasive insects, resistant to invasive fungi. Sole wood used to construct the tabernacle

and all its features. Chosen by Noah for the ark, by boat builders in ancient Egypt and modern Sudan.

It shall be the reward for Heaven's people.* Broken are we, out of sync with the universe while the acacia's not strayed

one millimeter from the sacred way. Listen how the Persian nightingale still sings plaintively dawn and dusk from its crown. A haunt from the beginning till now for Little owl Athene noctua, Crested lark, Southern Grey shrike,

White wagtail alike.

The acacia's austere stamina resonates with the hermit's solitude and silence.
Some say acacia's no match

for Scotch fir. Still, I much prefer

it in its solitary stand against grains of sand.

For a moment, in its presence, poisonous fumes hovering on the horizon (oil flares) fade to an illusion.

*Qu'ran/Sura 56:27-33)

My goal with "Citrullus Colocynthis" is to bring the reader up close and personal with one amazing plant. I tried to present its history and significance without getting too long-winded, choosing the prose form to allow me a bit more narrative freedom.

\section{Citrullus Colocynthis}

All day clouds hung over the desert. Wind blew as if to brew a great storm of hard long rain. But once again, nothing came of them. Beside a wadi, I waited - endured hunger and heat, slept among bitter apples: collocynth thriving on sandy loam, its perennial root sending forth scabrid vine-like stems. Solitary yellow flowers bloomed in the leaves' axils. Lemon-sized gourd-like fruit was filling up with soft white poisonous pulp in which flat ovate seeds would eventually please birds of passage who'd come to disperse them. Unable to resist, I tore one from the ground to transplant in my garden. But its delicate microscopical leaf structure caused it to wither within an hour. Clouds still hanging low, wind continuing to blow, I recalled how its fruit flourished profusely between Palestine's mountains and the Mediterranean's eastern shore, Gaza to Mt. Carmel-soil and climate all-sufficient for its growth. I took note: Leave things where they grow. Wild gourd of the Old Testament* - earth gall, exceeding bitterness — and yet, its nutty-flavored seeds taken from their poisonous enclosure, innocuous. In hard soil, widespread. Desert Bedouins grind and make a bread. Precious food source of one Central Saharan tribe-Tibboo Resade-seeds tramped on to remove the last traces of bitter pulp, cleaned by winnowing, mixed with ashes from camels' dung, placed on a smooth stone and rubbed with another to crush the testa, kernels sifted, boiled in water, dried in the sun, then mixed with desiccated powdered dates until finally palatable, nutritive. This is how we live: tearing through the toxic enclosure to what can sustain us.

$$
\text { *II Kings 4:38-40 }
$$

In the next poem, I use the directive voice to suggest the tasks the reader must do - listen and notice - if she is to participate in one herb's existence and thereby thrive in the desert herself.

\section{Desert Ecology 38: Umbel Family}

Here's the secret to thriving in this desert: taking part in the life of lady's-lace - glabrous herb sprouting in cultivated land. Listen 
intently till you hear the lower leaves of each bishop's-weed withering at anthesis.

Though you be heavy, notice how each fruiting umbel opens as if in flight. And though darkness appears to reign, how each onelong-peduncled - reflects one ray of mysterious, glorious light.

\section{Desert Ecology 47: Plantaginaceae}

The sparingly-hairy herb ispaghula flourishing on fine deposits in depressions. The densely

silky-hairy herb wedaina in sandy southern habitats. Buck's-horn plantainpinnatifid with acute lobes

forming basal rosettes on hard compact alluvial soil.

The lancelike ribwort, leaves tapering

to a petiole. So may my soul

rise up out of harsh aridity

into the silence unclaimed

by the world, starburst

of earth's truth, quantum

leap into the space between

depression and sky, safe

from malathion, far from

manicured lawns. May it catch

fire from the bee that is just now

honing in on one corolla,

heaven under its feet.

\section{Desert Ecology 48: Compositae}

The Compositae live as if my desert garden is heaven, possessing powers and magic, knowing how to sustain themselves through drought, will remain when I have ceased rambling about. I sit still as a Buddha, observe how the flowers crowd into heads on a common receptacle. I make just one of them

my companion, meander with it along the middle path between world's reality and vacuity, note its brief flowering — rays and discsday by day the sun harsher, note how the filaments are free, the anthers united, how some leaves are armed with thistles, others are not: aster-like Aaronsohnia, sagebrush, yellow sea daisy, white thistle with its leathery leaves, field marigold, Carduncellus (perennial thistle), knapweed (cobwebby herb), mum, with its naked receptacle, chicory with milky sap, the erect eclipta. Transplanted from their natural dominion: depressions with fine-textured sediments, gravelly soil, alfalfa fields, borders of irrigation canals. Their cross to bear: lash of sand, scarcity of rain. No fountain, no watermill. Persistent shamal. And yet, what jubilance-nearly sequestered from industrial pollution. What dignity—every spring blossoming stunningly, what fragile joy distracting from the yellow-tinged horizon.

Dazzling, humbling, silencing me as each one hints of forever.

\section{Desert Ecology 57: Cyperaceae}

When I grow weary traveling this Milky Way all alone, panic setting in, I go out to maritime sand or inland gravelly soil, meander scarab beetle-like among sedges, praising how they dress themselves in compound inflorescences, how they perfume ever so subtly but sweetly the desert air while masking fumes from the distant oil flare:

Cyperus effusus among ruins of a forgotten fishing/pearling village; smooth flatsedge lavishing its graces on marshy places; tuberous bulrush filling in margins where water spills - runners of its creeping rhizomes dilated in woody tubers.

Perennial herbs assuaging my rage touched off by the latest tragedyearthquake on the remote Tibetan plateau, children trapped in collapsed schools while purple nutsedge sends its long slender stolens bearing black tubers and leaf rosettes along the moist ground.

Sacredness of every day. Graceful, lilting sisters softening this harsh desert no human hands built, these sedges the only mosques in sight, their prostrate rhizomes kissing the ground, their flowers in dense heads or glumes the only gold domes to dominate this airy space.

Back in the city, in the cold sterility of MegaMart, my eyes smart as I consider whether I could live on the trigonous nut of Cyperus conglomerates - spare myself this weekly trip. Among Cyperaceae, 
dance and throw away my original plan?

How could I ever again live separated

from sedges and the song of the desert lark,

urging each creeping rhizome on?

This final poem was inspired by Anima Christi:

\section{Desert Ecology 46: Broomrape}

Heaven is under our feet as well as over our heads. Henry David Thoreau

Cistanche tubulosa, sanctify me.

Your fleshy stem covered with oblong-lanceolate scales, save me.

Your ovoid fruit, fill me with love.

Your thick, dense spike, strengthen me.

Your calyx with acute scarious-margined lobes, empower me.

Robust, perennial root parasite, hear me:

Within your littoral salt marshes, hide me.

May I never be separated from you.

Protect me by your yellow, blue, purple flowers from evil's power.

Call me, dear Desert hyacinth, at my death's hour.

\section{Acknowledgements}

“Acacia" -- Desert Ecology: Lessons and Visions (chapbook), Finishing Line Press, 2014.

"Citrullus Colocynthis" -- Ellipsis . . . Literature \& Art, 2010 (Vol. 46); Tamed by the Desert (a chapbook), Finishing Line Press, 2013.

"Desert Ecology 38: Umbel Family (Umbelliferae)" -Nimrod International Journal, Spring 2011;Conservation and Sustainable Use of Wild Plant Diversity, Orthodox Academy of Crete Publications, 2011; Tamed by the Desert (a chapbook), Finishing Line Press, 2013.

"Desert Ecology 46: Orobanchaceae (Broomrape)" -Conservation and Sustainable Use of Wild Plant Diversity, Orthodox Academy of Crete Publications, 2011; Desert Ecology: Lessons and Visions (chapbook), 2014.

"Desert Ecology 47: Plantaginaceae" -- Avocet, Fall 2010; Tamed by the Desert (a chapbook), Finishing Line Press, 2013.

"Desert Ecology 57: Cyperaceae"-- Off the Coast, Winter, 2012; Tamed by the Desert (a chapbook), Finishing Line Press, 2013.

"For Ali Sharif, Wildflower Expert" -- Conservation and Sustainable Use of Wild Plant Diversity, Orthodox Academy of Crete Publications, 2011; Desert Ecology: Lessons and Visions (chapbook), Finishing Line Press, 2014.

\section{REFERENCES}

[1] Online available from http://www.finaccord.com/press-release_2014_global-expatr iates_-size-segmentation-and-forecast-for-the-worldwide-ma rket.htm

[2] Online available from http://royalbotanicgarden.org/page/community-based-rangel and-rehabilitation

[3] Online available from http://www.qf.org.qa/app/media/1034 